\title{
Heart Rate Characteristics Monitoring and Viral Infection in the Neonatal Intensive Care Unit
}

William E King, MS, Jose Perez, MD

\section{Background}

There is a growing appreciation of the prevalence, morbidity, and mortality of viral infections in neonatal intensive care units (NICUs). Studies have found that $7-55 \%$ of premature infants tested positive for viruses (1-5). Outbreaks of viruses in NICUs have been described, including adenovirus (6-8), coronavirus (9), echovirus (10), herpes simplex virus (HSV, 11), influenza (12), parainfluenza $(13,14)$, respiratory syncytial virus (RSV, 15), rhinovirus/enterovirus (16-20), and rotavirus (21), while cytomegalovirus (CMV, 22) and respiratory viruses (23) have been detected among NICU patients undergoing sepsis evaluation. A viral infection is associated with a longer duration of mechanical ventilation (1) and length of stay $(1,5,24)$, prolonged antibiotic exposure (5), as well as a greater risk of bronchopulmonary dysplasia $(1,5)$ and mortality (24-26). Viral infections can be difficult to differentiate from bacterial infections without appropriate testing, which may contribute to unnecessary exposure to antibiotics (10).

Heart Rate Characteristics monitoring (HRC; aka HeRO monitoring, Medical Predictive Science Corporation, Charlottesville, Virginia) has been proven to decrease all-cause NICU mortality (27), mortality after infection (28), mortality at 18-22 months (29), mortality-or-severe-cerebral-palsy at 18-22 months (29), and NICU length of stay (30). The probable mechanism was earlier detection of infection, leading to earlier and more effective intervention (28). Indeed, the Heart Rate Characteristics index (HRCi; aka HeRO Score) has been shown to predict sepsis (31-41), UTI (42), NEC $(43,44)$, meningitis $(42)$, respiratory decompensation (45), extubation readiness $(46,47)$ and death $(48-52)$, and is associated with cytokines (53-55).

No previous attempts have been made to characterize the predictive ability of HRC monitoring to assess viral infection apart from other infections.

\section{Methods}

We analyzed 2989 Very Low Birth Weight (VLBW) patients enrolled in the HeRO randomized controlled trial (27). Briefly, patients at nine NICUs were randomized shortly after birth or transfer to one of two arms: either standard of care or standard of care plus HRC monitoring. There were no mandated interventions other than displaying the hourly $\mathrm{HRC}$ index to clinicians for those patients randomized to the HRC-display arm. Demographic and clinical variables were tracked for each patient, including all blood, urine, CSF, respiratory, peritoneal, and other cultures with their results.

Among all HRC index scores in the RCT database, cases were defined as HRC index scores in the 24-hour period immediately preceding culture of any type (blood, urine, CSF, respiratory, peritoneal, or other) with a result coded as CMV, HSV, RSV, or Other Viral. For each Other Viral code, the Comments field was examined manually, and an automated script was developed. Other Viral results containing the string "herpes" were re-coded as HSV. Other Viral results containing the strings "para," "flu," or "rota" were coded accordingly, whereas those where the Comments text entered by the research nurse included "urea," "myco," "hemophilus," or "haemophilus" were discarded from the analysis. All strings were converted to uppercase prior to matching, and the match for "para" was performed and coded prior to matching/ coding for "flu."

"We analyzed 2989 Very Low Birth Weight (VLBW) patients enrolled in the HeRO randomized controlled trial (27). Briefly, patients at nine NICUs were randomized shortly after birth or transfer to one of two arms: either standard of care or standard of care plus HRC monitoring."

We defined control (well patient) data as those scores, not within \pm 10 days of any blood, urine, CSF, respiratory, peritoneal, and other cultures, regardless of the result. HRC index scores within \pm 10 days of culture were ignored from this analysis unless they were defined as cases.

Analyses were performed with cases defined as a specific virus (CMV, HSV, Rotavirus, RSV, Parainfluenza, or Influenza) and as grouped by Order, then Class where the number of cases was small.

For both cases and controls, we analyzed the highest HRC index score in each 24-hour period (HeROMax24). We compared the distributions of HeRO scores between cases and controls using a two-tailed student t-test, setting significance at $p<0.05$. We also calculated the area under the curve of the receiver operating characteristics curve (AUC ROC) with 95\% confidence intervals. For the assessment of Sensitivity, Specificity, Positive Predictive Value, Negative Predictive Value, and Risk Ratio, we defined a threshold of HeROMax24 > 2.0. All calculations were performed in $\mathrm{R}$ ( $\mathrm{R}$ Core Team) (56).

\section{Results}

\section{"For both cases and controls, we analyzed the highest HRC index score in each 24-hour period (HeROMax24). We compared the distributions of HeRO scores between cases and controls using a two-tailed student t-test, setting significance at $p<0.05 . "$}

Baseline demographics of the patient population were described elsewhere and were not different between the two arms (27). 


\begin{tabular}{|c|c|c|c|c|c|c|c|c|}
\hline Cases & $\mathrm{n}$ & $\mathrm{ROC}(\mathrm{Cl})$ & Sens & Spec & PPV & NPV & Risk Rat & $\mathrm{p}$ \\
\hline HSV & 4 & $.910(.822-.999)$ & $50 \%$ & $92 \%$ & $.07 \%$ & $99.99 \%$ & $11.7 x$ & .10 \\
\hline CMV & 7 & $.708(.479-.936)$ & $43 \%$ & $92 \%$ & $.10 \%$ & $99.99 \%$ & $8.8 x$ & .16 \\
\hline $\begin{array}{l}\text { Order } \\
\text { Herpesvirales }\end{array}$ & 11 & .781 (.625-.938) & $45 \%$ & $92 \%$ & $.17 \%$ & $99.98 \%$ & $9.7 x$ & .035 \\
\hline Rotavirus & 2 & $.846(.544-1.00)$ & $50 \%$ & $85 \%$ & $.02 \%$ & $99.997 \%$ & $11.7 x$ & .49 \\
\hline $\begin{array}{l}\text { Class } \\
\text { incertae sedis }\end{array}$ & 13 & .791 (.655-.928) & $46 \%$ & $92 \%$ & $.20 \%$ & $99.98 \%$ & $10.0 x$ & .034 \\
\hline RSV & 6 & $.755(.552-.959)$ & $50 \%$ & $92 \%$ & $.10 \%$ & $99.99 \%$ & $11.7 x$ & .13 \\
\hline Parainfluenza & 4 & $.795(.633-.956)$ & $25 \%$ & $92 \%$ & $.03 \%$ & $99.99 \%$ & $3.90 x$ & .18 \\
\hline $\begin{array}{l}\text { Class } \\
\text { Monjiviricetes }\end{array}$ & 10 & .771 (.639-.903) & $40 \%$ & $92 \%$ & $.13 \%$ & $99.98 \%$ & $7.79 x$ & .045 \\
\hline Influenza & 7 & .884 (.778-.989) & $71 \%$ & $92 \%$ & $.17 \%$ & $99.99 \%$ & $29.2 x$ & .016 \\
\hline All Viral & 30 & $.806(.729-.883)$ & $50 \%$ & $92 \%$ & $.50 \%$ & $99.96 \%$ & $11.6 x$ & .0011 \\
\hline
\end{tabular}

Table 1. Predictive statistics comparing the maximum HeRO Score in the 24 hours prior to positive viral culture against maximum HeRO Score in 24 hours periods for controls. Sensitivity, Specificity, Positive Predictive Value, Negative Predictive Value, and Risk Ratio were all calculated at a threshold of $\mathrm{HeRO}>2.0$. Rows with significant results are bold.

Controls included a total of 37,768 days of HRC index scores. Table 1 details the results of these analyses. Positive viral cultures were rare in this population, with 30 positive results among 2989 patients. In each of the analyses, there was a trend toward higher HeRO Scores among the viral-positive cases when compared to controls. The trend was statistically significant whenever the number of cases was greater than seven, and non-significant whenever there were fewer. HeRO scores were statistically significantly higher for All Viruses, Influenza, Class Monjiviricetes, Class incertae sedis, and Order Herpesvirales. HSV, CMV, RSV, Parainfluenza showed non-significant trends toward higher HeRO

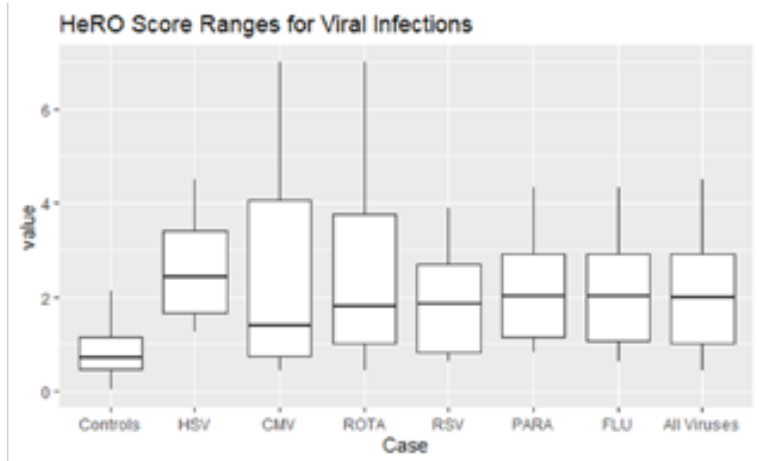

Figure 1. Boxplot of HeRO Score Ranges for Viral Infections. The box represents the $25^{\text {th }}$ and $75^{\text {th }}$ percentiles, the bold line represents the median. The whiskers represent $1.5 \times$ the IQR.
Scores. The AUC ROC was .806 (.729-.883) for All Viral infections, Sensitivity was $50 \%$, Specificity $92 \%$, Positive Predictive Value $.50 \%$, Negative Predictive Value $99.96 \%$, Risk Ratio 11.6x, $p=0.0011$. The boxplot in Figure 1 shows the range across all cases of each individual's maximum HeRO Score in the 24 hours prior to culture, with Controls for comparison. Figure 2 shows the trend in the range of each individual's maximum HeRO Score for the ten days before and after a positive viral culture compared with ranges of individual maximum HeRO Score in 24-hour periods for controls. HeRO Score rose dramatically, beginning four days prior to culture.

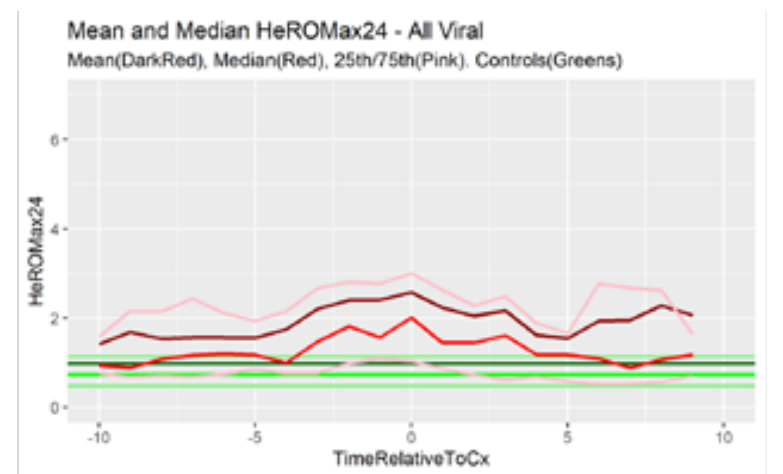

Figure 2. HeRO Scores for 10 days before and after positive viral infections (red) versus controls (green).

NEONATOLOGY TODAY is interested in publishing manuscripts from Neonatologists, Fellows, NNPs and those involved in caring for neonates on case studies, research results, hospital news, meeting announcements, and other pertinent topics.

Please submit your manuscript to: LomaLindaPublishingCompany@gmail.com 


\section{Discussion}

We found the HRC index to have excellent predictive characteristics for viral infections, similar to other previously described forms of infection. There are several important implications of this result. First, clinicians ordering a sepsis workup subsequent to an elevated HeRO score should consider including viral testing. A positive viral result could be used to initiate appropriate therapy and reduce unnecessary antimicrobial exposure in cases that might otherwise be considered clinical sepsis.

Second, given the nature of viral outbreaks within NICUs, HeRO monitoring acting as a NICU-wide surveillance system may improve the timing of diagnoses on an individual basis and earlier recognition of a viral outbreak within the NICU itself, leading to greater containment and reduced morbidity and mortality.

Third, in an era of increased global trade, supply chains, and travel, viral epidemics may become increasingly prevalent. Worldwide surveillance systems are challenged by variations in resources, availability, consistency of testing, terminology, and patient populations' heterogeneity. A worldwide network of HeRO-monitored NICUs would offer a unique signal among a cohort of relatively homogeneous patients where unexpected deviations from expected patterns in HeRO Score distributions may indicate increased incidence and transmission among the local community, perhaps prior to this signal manifesting through traditional means of surveillance.

Weaknesses of the current study include the retrospective nature of the analysis and the small number of positive viral cultures limiting our ability to provide statistically significant results for many individual types of viruses. Strengths of this analysis include a large number of patients at a geographically disperse set of NICUs conducted over a six-year period, as well as the consistency of results-both between types of viruses as well as comparing viruses to other forms of infection.

\section{Conclusion}

Heart Rate Characteristics monitoring has clinical utility in the assessment of viral infections in the NICU. Clinicians may be able to reduce unnecessary antibiotic exposure and improve therapy for symptomatic patients.

\section{"Heart Rate Characteristics monitoring has clinical utility in the assessment of viral infections in the NICU. Clinicians may be able to reduce unnecessary antibiotic exposure and improve therapy for symptomatic patients."}

Readers can also follow NEONATOLOGY TODAY via our Twitter Feed @NEOTODAY

\section{Bibliography}

1. Bennett NJ, Tabarani CM, Bartholoma NM, Wang D, Huang $D$, Riddell SW, Kiska DL, Hingre R, Rosenberg HF, Domachowske JB. Unrecognized viral respiratory tract infections in premature infants during their birth hospitalization: a prospective surveillance study in two neonatal intensive care units. Version 2. J Pediatr. 2012 Nov;161(5):814-8. doi: 10.1016/j.jpeds.2012.05.001. Epub 2012 Jun 12. PMID: 22694859; PMCID: PMC3731035.

2. Diniz EM, Vieira RA, Ceccon ME, Ishida MA, Vaz FA. Incidence of respiratory viruses in preterm infants submitted to mechanical ventilation. Rev Inst Med Trop Sao Paulo. 2005 Jan-Feb;47(1):37-44. doi: 10.1590/s003646652005000100007. Epub 2005 Feb 23. PMID: 15729473.

3. Gonzalez-Carrasco E, Calvo C, García-García ML, Beato $M$, Muñoz-Archidona C, Pozo F, Casas I. Viral respiratory tract infections in the neonatal intensive care unit. An Pediatr (Engl Ed). 2015 Apr;82(4):242-246. doi: 10.1016/j.anpede.2015.03.007. Epub 2015 Apr 25. PMID: 32289040; PMCID: PMC7146760.

4. Miller EK, Bugna J, Libster R, Shepherd BE, Scalzo PM, Acosta PL, Hijano D, Reynoso N, Batalle JP, Coviello S, Klein MI, Bauer G, Benitez A, Kleeberger SR, Polack FP. Human rhinoviruses in severe respiratory disease in very low birth weight infants. Pediatrics. 2012 Jan;129(1):e60-7. doi: 10.1542/peds.2011-0583. Epub 2011 Dec 26. PMID: 22201153; PMCID: PMC3255465.

5. Poole CL, Camins BC, Prichard MN, Faye-Petersen O, Hutto $C$. Hospital-acquired viral respiratory infections in neonates hospitalized since birth in a tertiary neonatal intensive care unit. J Perinatol. 2019 May;39(5):683-689. doi: 10.1038/ s41372-019-0318-9. Epub 2019 Feb 5. PMID: 30723275; PMCID: PMC7100243.

6. Sammons JS, Graf EH, Townsend S, Hoegg CL, Smathers $S A$, Coffin SE, Williams K, Mitchell SL, Nawab U, Munson D, Quinn G, Binenbaum G. Outbreak of Adenovirus in a Neonatal Intensive Care Unit: Critical Importance of Equipment Cleaning During Inpatient Ophthalmologic Examinations. Ophthalmology. 2019 Jan;126(1):137-143. doi: 10.1016/j. ophtha.2018.07.008. Epub 2018 Sep 1. PMID: 30180976.

7. Jones NK, Ranellou K, Zhang H, Jalal H. Adenovirus pseudo-outbreak in a large UK neonatal intensive care unit. Am J Infect Control. 2018 Dec;46(12):1411-1413. doi: 10.1016/j. ajic.2018.04.220. Epub 2018 May 21. PMID: 29799422.

8. Hysmith ND, Tanner MR, Arnold SR, Buckingham SC, Patel AR, Dhanireddy R, Comeaux K, Joyner J, Hoehn ME, DeVincenzo JP. Use of real-time semiquantitative PCR data in management of a neonatal intensive care unit adenovirus outbreak. Infect Control Hosp Epidemiol. 2018 Sep;39(9):1074-1079. doi: 10.1017/ice.2018.162. Epub 2018 Jul 18. PMID: 30019659.

9. Gagneur A, Sizun J, Vallet S, Legr MC, Picard B, Talbot PJ. Coronavirus-related nosocomial viral respiratory infections in a neonatal and paediatric intensive care unit: a prospective study. J Hosp Infect. 2002 May;51(1):59-64. doi: 10.1053/ jhin.2002.1179. PMID: 12009822; PMCID: PMC7134478.

10. Ho SY, Chiu CH, Huang YC, Chen CJ, Lien R, Chu SM, Huang CG, Tsao KC, Shih SR, Hsu JF. Investigation and successful control of an echovirus 11 outbreak in neonatal intensive care units. Pediatr Neonatol. 2020 Apr;61(2):180187. doi: 10.1016/j.pedneo.2019.09.012. Epub 2019 Oct 4. PMID: 31669107.

11. Hammerberg O, Watts J, Chernesky M, Luchsinger I, Rawls $W$. An outbreak of herpes simplex virus type 1 in an intensive care nursery. Pediatr Infect Dis. 1983 Jul-Aug;2(4):290-4. doi: 10.1097/00006454-198307000-00007. PMID: 6310534.

12. Cunney RJ, Bialachowski A, Thornley D, Smaill FM, Pennie $R A$. An outbreak of influenza $A$ in a neonatal intensive care 
unit. Infect Control Hosp Epidemiol. 2000;21(7):449-454. doi:10.1086/501786.

13. Singh-Naz N, Willy M, Riggs N. Outbreak of parainfluenza virus type 3 in a neonatal nursery. Pediatr Infect Dis J. 1990 Jan;9(1):31-3. doi: 10.1097/00006454-199001000-00007. PMID: 2153949.

14. Maeda $H$, Haneda K, Honda Y. Parainfluenza virus type 3 outbreak in a neonatal intensive care unit. Pediatr Int. 2017 Nov;59(11):1219-1222. doi: 10.1111/ped.13389. PMID: 29359411; PMCID: PMC7167953.

15. Halasa NB, Williams JV, Wilson GJ, Walsh WF, Schaffner W, Wright PF. Medical and economic impact of a respiratory syncytial virus outbreak in a neonatal intensive care unit. $\mathrm{Pe}$ diatr Infect Dis J. 2005 Dec;24(12):1040-4. doi: 10.1097/01. inf.0000190027.59795.ac. PMID: 16371862.

16. El Idrissi KR, Isabel S, Carbonneau J, Lafond M, Quach C, Caya C, Fontela PS, Beltempo M, Boivin G, Lefebvre MA, Papenburg J. Molecular and epidemiologic investigation of a rhinovirus outbreak in a neonatal intensive care unit. Infect Control Hosp Epidemiol. 2019 Feb;40(2):245-247. doi: 10.1017/ice.2018.311. Epub 2018 Dec 5. PMID: 30516128.

17. Reese SM, Thompson M, Price CS, Young HL. Evidence of nosocomial transmission of human rhinovirus in a neonatal intensive care unit. Am J Infect Control. $2016 \mathrm{Mar}$ 1;44(3):355-7. doi: 10.1016/j.ajic.2015.10.018. Epub 2016 Jan 5. PMID: 26775935; PMCID: PMC7115317.

18. van Piggelen RO, van Loon AM, Krediet TG, Verboon-Maciolek MA. Human rhinovirus causes severe infection in preterm infants. Pediatr Infect Dis J. 2010 Apr;29(4):364-5. doi: 10.1097/INF.0b013e3181c6e60f. PMID: 19935443.

19. Steiner M, Strassl R, Straub J, Böhm J, Popow-Kraupp T, Berger A. Nosocomial rhinovirus infection in preterm infants. Pediatr Infect Dis J. 2012 Dec;31(12):1302-4. doi: 10.1097/ INF.0b013e31826ff939. PMID: 22926220.

20. Reid AB, Anderson TL, Cooley L, Williamson J, Mcgregor $A R$. An outbreak of human rhinovirus species $C$ infections in a neonatal intensive care unit. Pediatr Infect Dis J. 2011 Dec;30(12):1096-5. doi: 10.1097/INF.0b013e31822938d7. PMID: 21747322.

21. Tsai HC, Tsai MT, Sheng WH, Wang JT, Tsao PN, Chou HC, Chen CY, Chang LY, Lu CY, Huang LM. Rotavirus Gastroenteritis Outbreaks in a neonate intermediate care unit: Direct detection of rotavirus from a computer keyboard and mouse. J Microbiol Immunol Infect. 2019 Dec;52(6):888-892. doi: 10.1016/j.jmii.2019.03.010. Epub 2019 May 18. PMID: 31178351 .

22. Ronchi A, Ouellette CP, Mejías A, Salamon D, Leber A, Pugni L, Mosca F, Sánchez PJ. Detection of cytomegalovirus in saliva from infants undergoing sepsis evaluation in the neonatal intensive care unit: the VIRIoN-C study. J Perinat Med. 2018 Dec 19;47(1):90-98. doi: 10.1515/jpm-2018-0021. PMID: 29768249.

23. Ronchi A, Michelow IC, Chapin KC, Bliss JM, Pugni L, Mosca F, Sánchez PJ. Viral respiratory tract infections in the neonatal intensive care unit: the VIRloN-I study. J Pediatr. 2014 Oct;165(4):690-6. doi: 10.1016/j.jpeds.2014.05.054. Epub 2014 Jul 12. PMID: 25027362; PMCID: PMC7094497.

24. Tran C, Bennett MV, Gould JB, Lee HC, Lanzieri TM. Cytomegalovirus Infection among Infants in Neonatal Intensive Care Units, California, 2005 to 2016. Am J Perinatol. 2020 Jan;37(2):146-150. doi: 10.1055/s-0039-1683958. Epub 2019 Mar 20. PMID: 30895580; PMCID: PMC6754307.

25. Fernandes ND, Sthapit B, Mhanna M, Abughali N. Evaluation of suspected neonatal herpes simplex virus infection in preterm versus term newborns in the neonatal intensive care unit. J Neonatal Perinatal Med. 2020 Feb 20. doi: 10.3233/ NPM-190334. Epub ahead of print. PMID: 32083595.

26. Dramowski A, Aucamp M, Bekker A, Mehtar S. Infectious disease exposures and outbreaks at a South African neonatal unit with review of neonatal outbreak epidemiology in Africa. Int J Infect Dis. 2017 Apr;57:79-85. doi: 10.1016/j. ijid.2017.01.026. Epub 2017 Feb 1. PMID: 28161461.

27. Moorman JR, Carlo WA, Kattwinkel J, Schelonka RL, Porcelli PJ, Navarrete CT, Bancalari E, Aschner JL, Whit Walker M, Perez JA, Palmer C, Stukenborg GJ, Lake DE, Michael $O$ 'Shea T. Mortality reduction by heart rate characteristic monitoring in very low birth weight neonates: a randomized trial. J Pediatr. 2011 Dec;159(6):900-6.e1. doi: 10.1016/j. jpeds.2011.06.044. Epub 2011 Aug 24. PMID: 21864846; PMCID: PMC3215822.

28. Fairchild KD, Schelonka RL, Kaufman DA, Carlo WA, Kattwinkel J, Porcelli PJ, Navarrete CT, Bancalari E, Aschner JL, Walker MW, Perez JA, Palmer C, Lake DE, O'Shea TM, Moorman JR. Septicemia mortality reduction in neonates in a heart rate characteristics monitoring trial. Pediatr Res. 2013 Nov;74(5):570-5. doi: 10.1038/pr.2013.136. Epub 2013 Aug 13. PMID: 23942558; PMCID: PMC4026205.

29. Schelonka RL, Carlo WA, Bauer CR, Peralta-Carcelen M, Phillips V, Helderman J, Navarrete CT, Moorman JR, Lake $D E$, Kattwinkel J, Fairchild KD, O'Shea TM. Mortality and Neurodevelopmental Outcomes in the Heart Rate Characteristics Monitoring Randomized Controlled Trial. J Pediatr. 2020 Apr;219:48-53. doi: 10.1016/j.jpeds.2019.12.066. Epub 2020 Feb 4. PMID: 32033793; PMCID: PMC7096280.

30. Swanson JR, King WE, Sinkin RA, Lake DE, Carlo WA, Schelonka RL, Porcelli PJ, Navarrete CT, Bancalari E, Aschner JL, Perez JA, O'Shea TM, Walker MW. Neonatal Intensive Care Unit Length of Stay Reduction by Heart Rate Characteristics Monitoring. J Pediatr. 2018 Jul;198:162-167. doi: 10.1016/j.jpeds.2018.02.045. Epub 2018 Apr 24. PMID: 29703576.

31. Griffin MP, Moorman JR. Toward the early diagnosis of neonatal sepsis and sepsis-like illness using novel heart rate analysis. Pediatrics. 2001 Jan;107(1):97-104. doi: 10.1542/ peds.107.1.97. PMID: 11134441

32. Kovatchev BP, Farhy LS, CaoH, Griffin MP, Lake DE, Moorman $J R$. Sample asymmetry analysis of heart rate characteristics with application to neonatal sepsis and systemic inflammatory response syndrome. Pediatr Res. 2003 Dec;54(6):8928. doi: 10.1203/01.PDR.0000088074.97781.4F. Epub 2003 Aug 20. PMID: 12930915.

33. Griffin MP, O'Shea TM, Bissonette EA, Harrell FE Jr, Lake DE, Moorman JR. Abnormal heart rate characteristics preceding neonatal sepsis and sepsis-like illness. Pediatr Res. 2003 Jun;53(6):920-6. doi: 10.1203/01.PDR.0000064904.05313. D2. Epub 2003 Mar 19. PMID: 12646726.

34. Griffin MP, Lake DE, Moorman JR. Heart rate characteristics and laboratory tests in neonatal sepsis. Pediatrics. 2005 Apr;115(4):937-41. doi: 10.1542/peds.2004-1393. PMID: 15805367

35. Moorman JR, Lake DE, Griffin MP. Heart rate characteristics monitoring for neonatal sepsis. IEEE Trans Biomed Eng. 2006 Jan;53(1):126-32. doi: 10.1109/TBME.2005.859810. PMID: 16402612.

36. Griffin MP, Lake DE, O'Shea TM, Moorman JR. Heart rate characteristics and clinical signs in neonatal sepsis. Pediatr Res. 2007 Feb;61(2):222-7. doi: 10.1203/01. pdr.0000252438.65759.af. PMID: 17237726.

37. Moorman JR, Delos JB, Flower AA, Cao H, Kovatchev BP, Richman JS, Lake DE. Cardiovascular oscillations at the bedside: early diagnosis of neonatal sepsis using heart rate characteristics monitoring. Physiol Meas. 2011 Nov;32(11):1821-32. doi: 10.1088/0967-3334/32/11/S08. Epub 2011 Oct 25. PMID: 22026974; PMCID: PMC4898648.

38. Fairchild KD. Predictive monitoring for early detection of sepsis in neonatal ICU patients. Curr Opin Pediatr. 2013 
Apr;25(2):172-9. doi: 10.1097/MOP.0b013e32835e8fe6. PMID: 23407184.

39. Lake DE, Fairchild KD, Moorman JR. Complex signals bioinformatics: evaluation of heart rate characteristics monitoring as a novel risk marker for neonatal sepsis. J Clin Monit Comput. 2014 Aug;28(4):329-39. doi: 10.1007/s10877013-9530-x. Epub 2013 Nov 19. PMID: 24248424; PMCID: PMC4026344.

40. Hicks JH, Fairchild KD. Heart rate characteristics in the NICU: what nurses need to know. Adv Neonatal Care. 2013 Dec;13(6):396-401. doi: 10.1097/ANC.0000000000000031. PMID: 24300957.

41. Pugni L, Ronchi A, Bizzarri B, Pietrasanta C, Araimo G, Ghirardi $B$, Casciati MC, Perniciaro S, Casartelli M, Mosca F. [HEART RATE CHARACTERISTICS INDEX SCORE: Is it Useful to Predict Neonatal Sepsis?]. La Pediatria Medica \# Chirurgica - Medical and Surgical Pediatrics Volume 37, N. 1, January-March 2015. Italian.

42. Weitkamp JH, Aschner JL, Carlo WA, Bancalari E, Perez JA, Navarrete CT, Schelonka RL, Whit Walker M, Porcelli P Jr, O'Shea TM, Palmer C, Grossarth S, Lake DE, Fairchild KD. Meningitis, urinary tract, and bloodstream infections in very low birth weight infants enrolled in a heart rate characteristics monitoring trial. Pediatr Res. 2020 Jun;87(7):1226-1230. doi: 10.1038/s41390-019-0701-4. Epub 2019 Dec 4. PMID: 31801155; PMCID: PMC7255929.

43. Stone ML, Tatum PM, Weitkamp JH, Mukherjee AB, Attridge J, McGahren ED, Rodgers BM, Lake DE, Moorman JR, Fairchild KD. Abnormal heart rate characteristics before clinical diagnosis of necrotizing enterocolitis. J Perinatol. 2013 Nov;33(11):847-50. doi: 10.1038/jp.2013.63. Epub 2013 May 30. PMID: 23722974; PMCID: PMC4026091.

44. Sullivan $B A$, Fairchild $K D$. Predictive monitoring for sepsis and necrotizing enterocolitis to prevent shock. Semin Fetal Neonatal Med. 2015 Aug;20(4):255-61. doi: 10.1016/j. siny.2015.03.006. Epub 2015 Mar 29. PMID: 25823938.

45. Clark MT, Vergales BD, Paget-Brown AO, Smoot TJ, Lake DE, Hudson JL, Delos JB, Kattwinkel J, Moorman JR. Predictive monitoring for respiratory decompensation leading to urgent unplanned intubation in the neonatal intensive care unit. Pediatr Res. 2013 Jan;73(1):104-10. doi: 10.1038/ pr.2012.155. Epub 2012 Nov 8. PMID: 23138402; PMCID: PMC5321074.

46. Alonzo CJ, Fairchild KD. Dexamethasone effect on heart rate variability in preterm infants on mechanical ventilation. $J$ Neonatal Perinatal Med. 2017;10(4):425-430. doi: 10.3233/ NPM-16157. PMID: 29286932.

47. Goel N, Chakraborty M, Watkins WJ, Banerjee S. Predicting Extubation Outcomes-A Model Incorporating Heart Rate Characteristics Index. J Pediatr. 2018 Apr;195:53-58.e1. doi: 10.1016/j.jpeds.2017.11.037. Epub 2018 Jan 10. PMID: 29329913.

48. Fairchild $K D$, Sinkin $R A$, Davalian F, Blackman AE, Swanson JR, Matsumoto JA, Lake DE, Moorman JR, Blackman $J A$. Abnormal heart rate characteristics are associated with abnormal neuroimaging and outcomes in extremely low birth weight infants. J Perinatol. 2014 May;34(5):375-9. doi: 10.1038/jp.2014.18. Epub 2014 Feb 20. PMID: 24556979.

49. Vergales BD, Zanelli SA, Matsumoto JA, Goodkin HP, Lake $D E$, Moorman JR, Fairchild KD. Depressed heart rate variability is associated with abnormal EEG, MRI, and death in neonates with hypoxic ischemic encephalopathy. Am J Perinatol. 2014 Nov;31(10):855-62. doi: 10.1055/s-00331361937. Epub 2013 Dec 17. PMID: 24347263.

50. Griffin MP, O'Shea TM, Bissonette EA, Harrell FE Jr, Lake DE, Moorman JR. Abnormal heart rate characteristics are associated withneonatal mortality. PediatrRes. 2004May;55(5):7828. doi: 10.1203/01.PDR.0000119366.21770.9E. Epub 2004
Jan 22. PMID: 14739356.

51. Griffin MP, Lake DE, Bissonette EA, Harrell FE Jr, O'Shea TM, Moorman JR. Heart rate characteristics: novel physiomarkers to predict neonatal infection and death. Pediatrics. 2005 Nov;116(5):1070-4. doi: 10.1542/peds.2004-2461. PMID: 16263991.

52. Sullivan BA, McClure C, Hicks J, Lake DE, Moorman JR, Fairchild KD. Early Heart Rate Characteristics Predict Death and Morbidities in Preterm Infants. J Pediatr. 2016 Jul;174:57-62. doi: 10.1016/j.jpeds.2016.03.042. Epub 2016 Apr 22. PMID: 27113378; PMCID: PMC5672906.

53. Fairchild KD, Saucerman JJ, Raynor LL, Sivak JA, Xiao $Y$, Lake DE, Moorman JR. Endotoxin depresses heart rate variability in mice: cytokine and steroid effects. Am J Physiol Regul Integr Comp Physiol. 2009 Oct;297(4):R1019-27. doi: 10.1152/ajpregu.00132.2009. Epub 2009 Aug 5. PMID: 19657103; PMCID: PMC2763816.

54. Fairchild KD, Srinivasan V, Moorman JR, Gaykema RP, Goehler LE. Pathogen-induced heart rate changes associated with cholinergic nervous system activation. Am J Physiol Regul Integr Comp Physiol. 2011 Feb;300(2):R330-9. doi: 10.1152/ajpregu.00487.2010. Epub 2010 Nov 10. PMID: 21068197; PMCID: PMC3043803.

55. Raynor LL, Saucerman JJ, Akinola MO, Lake DE, Moorman JR, Fairchild KD. Cytokine screening identifies NICU patients with Gram-negative bacteremia. Pediatr Res. 2012 Mar;71(3):261-6. doi: 10.1038/pr.2011.45. Epub 2012 Jan 25. PMID: 22278182; PMCID: PMC3552187.

56. $R$ Core Team (2019). $R$ : A language and environment for statistical computing. $R$ Foundation for Statistical Computing, Vienna, Austria. URL http://www.R-project.org/

Disclosure: Mr. King is employed by MPSC, manufacturer of HeRO. Dr. Perez reports nothing to disclose.

\section{NT}

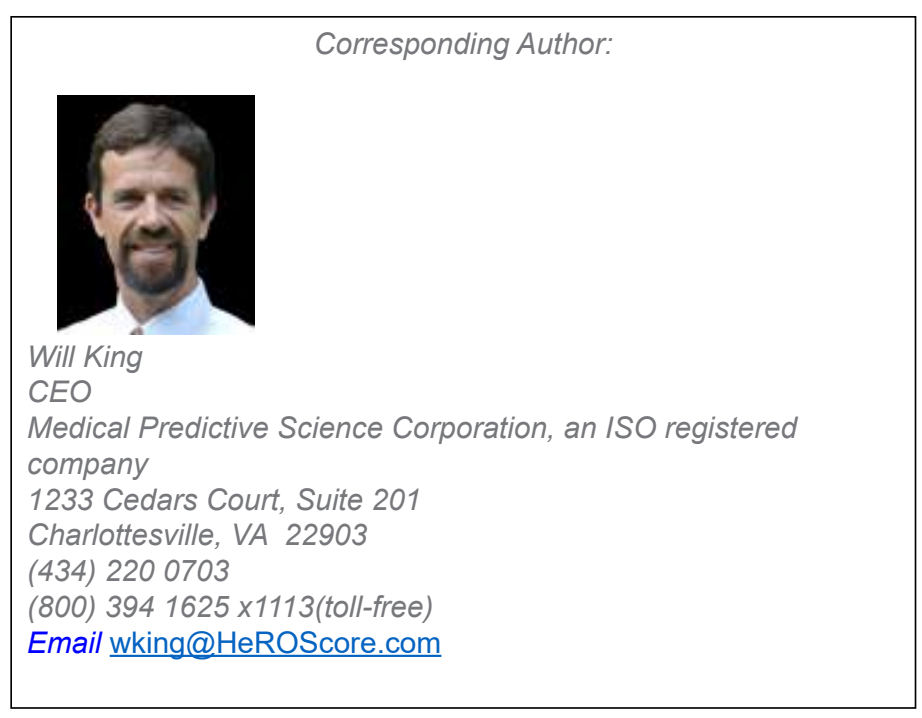




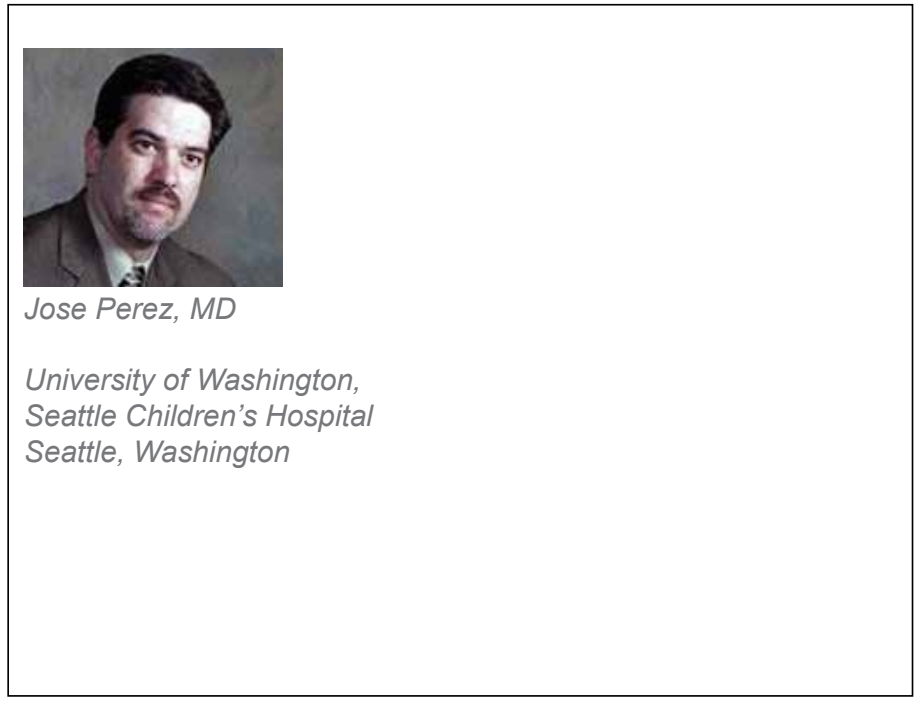

FREE RESOURCES FOR YOUR NICU

\section{Coping During COVID-19

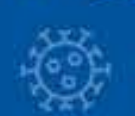

Targeted interventions to improve the mental health of parents, infants, families, and providers

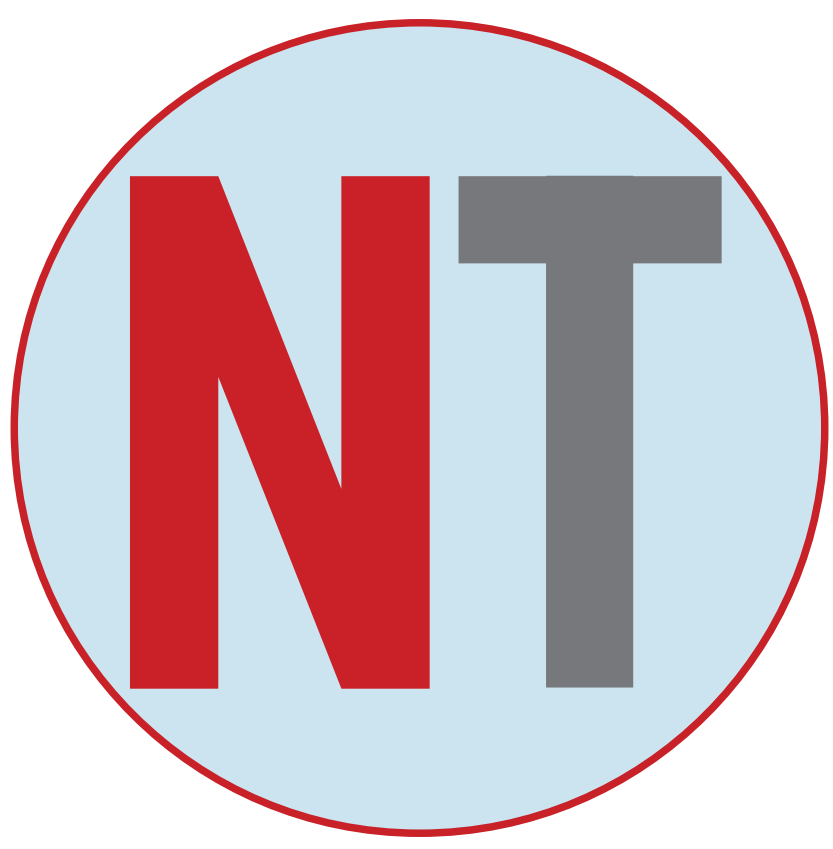

BONDING WITH YOUR BABY
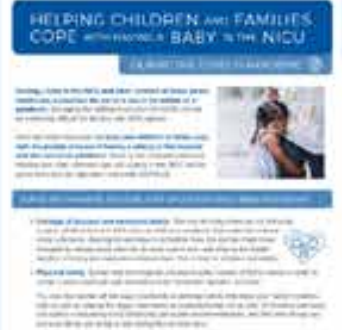

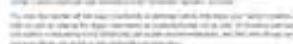
(6)

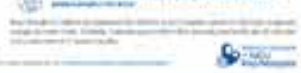

CAREGIVERS NEED CARE TOO

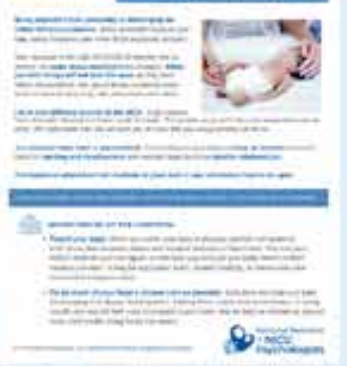

HELPING CHILDREN AND FAMILIES COPE

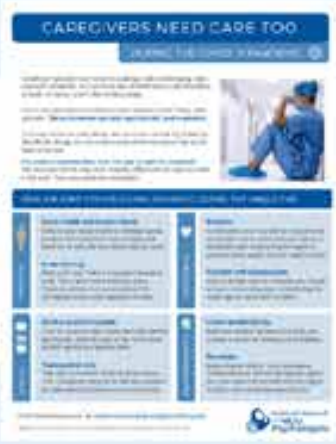
@NEOTO
Readers can also follow NEONATOLOGY

\section{via our Twitter Feed}

National Network of NICU Psychologists 